\title{
"Divide et impera"? Office accumulation in state-wide parties and the process of decentralization in Spain
}

\author{
Javier Astudillo \\ Universitat Pompeu Fabra \\ Department of Political and Social Sciences \\ Ramon Trias Fargas 25-27 \\ 08005 Barcelona, Spain \\ javier.astudillo@upf.edu
}

\section{DRAFT VERSION: SEPTEMBER 2010}

\begin{abstract}
Most recent studies about internal power distribution within state-wide parties in previous unitary countries, like Spain, show that they have changed less than it was initially expected. But how national party leaders are able to counteract the decentralizing pressures that the first studies in this field underlined is still to be explained. In this article we reformulate a mechanism for national political leaders to have their parliamentary parties under control that Van Biezen has suggested for new European democracies. We argue that keeping party and public offices apart at the regional level is a vital part of a chain of command whereby national party leaders are able to control their party's regional governments. Using for the first time a quantitative analysis of national and regional elites we show that office overlapping is thus substantially less intense at the regional level that at the national level in the two main Spanish state-wide parties, and that this feature is related to regional politicians' degree of autonomy. Still, this 'divide et impera' strategy is less employed over time.
\end{abstract}

\section{Introduction}

In the last 30 years a large number of European and Latin American countries have experienced a transformation in their government structure (Rodden 2004). The creation of regional governments has developed a new arena of political competition and policymaking. This poses great challenges and strains on political parties. Initially, it was expected that the adoption of decentralizing institutional reforms triggers in turn the decentralization of state-wide parties (Maravall 1991, Hopkin 2003). More recently 
scholars have argued such parties have been able to resist such decentralizing pressures (Fabre 2008, Bratberg 2010). However, no clear mechanism has been given to explain how parties counteract the electoral or fiscal consequences of decentralizing reforms. How can national elites control their regional colleagues when new regional governments acquire substantial political power and fiscal resources?

In this article we suggest, and test, a possible way in which national party leaders can keep in line their regional colleagues even when the latter are in power at the subnational level. By keeping party and public offices separate at the regional level, national party elites establish a chain of command whereby they are able to control their regional extraparliamentary parties, and in so doing control the parliamentary party at that level, and finally the regional administration.

In the next section we review the academic debate on the vertical distribution of power within state-wide parties in decentralizing states, and present a possible strategy national party leaders can use to control their regional counterparts in new, multi-level democracies. In section three we justify the interest of the Spanish case (the country where we test the plausibility of this control mechanism), and present the expectations we get from the theoretical arguments previously reviewed and finally the database used to test them. Section four offers the results of our empirical analysis. The final section concludes.

\section{The academic debate on the decentralization of integrated, state-wide parties in decentralizing states}

Much of the controversy on the effects of political decentralization of unitary countries on their state-wide parties is due to the confusion between two distinct dimensions related to the territorial aspects of politics: one structural and another behavioural (Janda 1980, Deschouwer 2006).

The structural dimension refers to the number of levels of government and regions within the country a party operates, and the organizational linkages that a party develops to connect its different parts (Deschouwer 2006). When parties operate at 
different levels of government, and develop common party membership, finances, and governance structure, they are usually termed "integrated" parties. In addition, if they operate in all regions of a country, they are called "state-wide parties". The parties we are interested in have both characteristics. But, as Thorlakson (2009) has recently remarked, the structural dimension does not describe per se how power is exercised within a party.

The second dimension, which is what organizational (de)centralization is really about, refers to the vertical distribution of power between party organs at different party levels (Duverger 1988:52, Janda 1980:108). This vertical distribution has been typically measured with scales that represent the level at which party decisions are taken (Janda 1980). These scales usually range from one extreme of decentralization, in which the decision in question is taken at local party level, to extreme centralization, where decisions are taken exclusively by the national party offices.

Later studies have clarified that within these extremes, two quite distinct arrangements can occur. Either both national and sub-national party organs can influence each other, or each organizational level is autonomous from the other. Thorlakson (2009:160-163, Detterbeck and Hepburn 2009) try to identify these distinct situations by adding two additional concepts, that of "influence" and "autonomy". Influence refers "to the degree to which the [regional] party organization is an important force in the federal party structure". Autonomy refers to "the freedom of the [regional] level of the party to conduct its affairs without interference from the federal party". As we will explain later, this article will concentrate on how national party leaders can try to limit the degree of autonomy of regional party elites.

With regard to the reasons for variation in the internal distribution of party power within state-wide parties in decentralizing states, existing literature has not reached a clear consensus on what degree of (de)centralization we should expect to find. As mentioned, the first studies tended to expect decentralizing institutional reforms to trigger a decentralization of state-wide parties. This was because either the national party leadership had to give some leeway to its regional branch organizations so that they could satisfy their regional electorates in order to win sub-national elections, or because, as an unwanted consequence, new echelons of regional party leaders could use their 
new role in policy-making, as well as their access to large regional budgets, to build strong personal followings in their party regional branch ${ }^{1}$.

Some also argue that the vertical distribution of power within parties is somewhat conditional. The main contingent factor that has been presented is the incumbency status of central and regional party leaders, holding executive office can provide them with resources that they can use in intra-party relations (Roller and Van Houten 2003, Fabre 2008, Hopkin 2009). Factional divisions within the "dominant coalitions" that rule national party organizations are suggested as another factor (Maravall 1991, Fabre 2008).

Finally, the latest studies have stressed that party organization is shaped by the origins of the party as a result of a path-dependency effect (Hopkin 2009, Thorlakson 2009). Hence parties founded with power concentrated at the upper organizational echelons would be resistant to meaningful internal decentralisation. Obviously, if parties had different original vertical distributions of power, we would expect differences to remain (Bratberg 2010). This path-dependency wave of studies tends to also make reference to the conclusions reached by scholars studying party change that argue environmental factors are mediated by internal ones (Harmel 2005:130).

The limitation of such "origins-matter" studies, however, is that they tend only to prove that a party had certain characteristics at a time " $\mathrm{t}$ ", and the same, or very similar ones, at " $t+1$ " (Bratberg 2010). But the exact mechanisms why changes do not happen, or are less pronounced than expected, are missing. Instead they are substituted by metaphors such as "institutions are sticky", "origins matter", or the existence of "institutional inertias". The problem with their cursory use of the path-dependency thesis is that it introduces a certain puzzle. The Spanish state, for example, has a tradition of centralism, but this has not impeded it from becoming "one of the most decentralized" (OECD 2005:101). Similarly comments can be made for the the British state (Laffin, Shaw, and Taylor 2007:89). Why then are partisan institutions more resistant to decentralization than state ones? Why are "organizational legacies" more important for the former? 
We do not question that state-wide parties in decentralizing countries have changed less than originally expected. But unless we offer some causal mechanism of how national partisan leaderships are able to resist "decentralizing pressures", the previous puzzle remains. Thus, we wonder how national elites are able to control powerful regional elites that have access to new political competencies and fiscal resources?

For new democracies Van Biezen (2000) has indirectly offered a possible explanation for the unexpected finding that, despite the fact that sub-national governments may be quite powerful, regional politicians that belong to state-wide parties are controlled by their national colleagues. Referring only to national politics, she shows that in these democracies the "party in central office" dominates over the "parliamentary party", as well as there is a tendency towards a high level of accumulation of party and public offices (for example, prime ministers are usually also the official leader of the party organization).

The connexion between these two features seems to have a rationale. In parliamentary systems, powerful prime ministers have an Achilles's heel, the political executive emerges from the legislature whose confidence it must enjoy and to whom it is formally accountable. In consequence, for prime ministers to exercise their predominance over the legislative (a phenomenon often called "presidentialization of politics") they must enjoy a high degree of parliamentary party discipline (Poguntke and Webb 2005, 3). This discipline can be achieved through different ways (Bowler, Farrell and Katz 1999; Kam 2009). Van Biezen argues that new democracies tend to ensure that the "party central office" has power over the parliamentary party through, for example, control of candidate selection mechanisms. If, in addition, top public office holders (either the prime minister, or the parliamentary leader if the party is in opposition) occupy the office of top party organizational leader, and this office holds extensive authority over the party apparatus, the chain of command is closed. Public office holders are able to control their parliamentary support bases thanks they are also the official party leaders, and party apparatus control the parliamentary parties.

From Van Biezen's analysis we can deduce, in consequence, that if, at the national level, the incumbent extra-parliamentary party dominates over the parliamentary party, but the top public office holder does not also occupy the top party office (or this office 
is largely honorific), then it is the party machine and its "dominant coalition" that controls collectively the national executive. We will have, following Poguntke and Webb's terminology (2005:5-7) a "partified form of government". But, if this lack of office accumulation occurs at the regional level, and at the same time the regional extraparliamentary party machine depends through the intermediation of the regional extraparliamentary organization on the "central party machinery" which in turn is controlled by national political leaders, then these leaders, by using this chain of command, can prevail over regional governments presided by their regional party branches, no matter how powerful regional administrations were in terms of political competencies and fiscal resources. Thus the application of the Van Biezen's study to the regional level offers us a plausible strategy for national party leaders, in new, multilevel and parliamentarian democracies, to control their regional counterparts, and in so doing it offers an explanation for the fact that we find centralized parties in decentralized states.

\section{The Spanish case, presentation of expectations, and explanation of the database}

In this article we are going to evaluate if keeping regional party and public offices separate can be a strategy for national party leaders to control their regional counterparts in the specific case of Spain. This country is, according to the literature, one of the countries where we should have expected far-reaching decentralizing institutional reforms to have triggered a process of state-wide party decentralization, however they are still quite centralized (Montero 2005, Van Biezen and Hopkin 2005, and Fabre 2008).

With regards to its institutional framework, Spain belongs to the third wave type of democracies, so Van Biezen's argument about the effects of office overlapping should apply. This country is also a multi-level polity. In about two decades, this country evolved from the unitary and highly centralized state it was under Franco's rightwing dictatorship to an almost federal state structure (Moreno 1997). The 1978 constitution set the scene for a polity consisting of 17 "autonomous communities" (comunidades autónomas). These regional governments can develop self-rule in certain domains and 
share rule with the central government in others. Although the 1978 Constitution envisaged autonomous communities with various degrees of self rule, this initial asymmetric design set in motion a dynamic of competition between regions to obtain financial and legal resources from the central government, and it fostered the decentralization process.

Expenditure managed by central authorities fell substantially during the decentralization process, from 90.5 percent of total expenditure in 1978 to 50.9 percent in 2004 . The percentage of public expenditure managed by the regional governments increased from 2.9 percent in 1981 to 36 percent in 2004 (Mitxelena 2006). The important role of the regional governments can also be assessed by its size as a public employer. In 2007 the central state employed just $22 \%$ of total public employees, regional administration 50.2\%, and local authorities 24\% (Gómez Sala and Sánchez 2009:22).

The result is that Spanish decentralization has gone further than the French or Italian one (OCDE 2005), and has been under way longer than British devolution. In consequence, if the main Spanish state-wide parties were not fully decentralized, it would be difficult to argue that this is explained by Spanish regional governments being weak, as could be the case in France, or that not enough time has passed for new institutions to show their effects on parties, as could be suggested in the British case (Laffin, Shaw and Taylor 2007:105).

Having said that, the few comparative studies about the vertical distribution of power within the main Spanish, integrated, state-wide parties establish that they are still rather centralized, although the Spanish socialist party, the Partido Socialista Obrero Español (PSOE), less so than the right-wing People's Party, Partido Popular (PP), formerly Alianza Popular (AP) (Montero 2005; Fabre 2008).

The PSOE was founded at the end of the $19^{\mathrm{Th}}$ century, and during the Franco dictatorship (1939-1975) maintained some sort of clandestine existence. After the return to democracy, it quickly become hegemonic within the left and was the main opposition party from 1977 to 1982 . The Socialist party won the elections from 1982 to 1993 , and again since 2004. AP was created in 1976 as a loose coalition of former Francoist politicians. In 1989 a substantial number of centrist politicians joint the party, which 
changed its name to Partido Popular. After an initial poor electoral performance, it became the main opposition party by 1982 and was in national government from 1996 to 2004. In addition, most regional governments are controlled by them (see figure 1).

\section{[Figure 1]}

In spite of their distinct ideological profiles, and a more intense preference for state decentralization in the case of the Socialist party as a reaction to the centralism of the Franco dictatorship, both the PSOE and the PP, as cases of parties formed (or rebuilt) in new democracies (Van Biezen 2003), have similar top-down organizational origins (Méndez 2000; García-Guereta 2001). Although the PSOE defines itself as a "federal party" and the PP as a "national party" with a "regionalised and decentralised organization", in practice their territorial structure is quite similar.

Since the return of democracy, both parties articulated their sub-national organization following the political-administrative structure of Spain: local, provincial and regional. As a result both parties are examples of an "integrated structure". They operate across territorial levels as one single organization with regional party branches, except in two autonomous communities: Catalonia in the case of the socialists, and, until 2008, Navarre in the case of the conservatives. The sub-national party branches have their own party bureaucracy and organs of self-government. From a formal point of view both parties have a decentralized regional branch leadership selection process but centralized control over the selection of candidates for regional elections (Méndez and Orte 2010, Astudillo 2010) ${ }^{2}$. In practice, both parties are presently characterized as "hierarchical and top-down organizations with strong oligarchic tendencies, concentrating power at the highest echelons of the party in the hands of a small elite" (Van Biezen and Hopkin 2005:111).

However, such analyses give a snapshot of their vertical distribution of power. Méndez and Orte (2010) have defended the existence of various stages in the process of decentralization in the specific case of the PSOE. In the 1980s, strong party centralization occurred. But, during the 1990s, as political decentralization gained momentum, and especially after the PSOE went out of national government in 1996, they argue that regional socialist elites gained considerable power. Finally, after its 
return to the national government in 2004, a certain "recentralization" has taken place. With respect to the PP, studies show a more linear evolution from a highly centralised party to a slightly less one (García-Guereta 2001, Astudillo 2010).

The fact that the PSOE and the PP are still quite centralized, in spite of state decentralization, seems to support the path-dependency thesis about the resilience of the structures laid down in the formative period of a party. However the question of how come partisan structures are more resistant to decentralization than state institutions remains. In addition, the conclusion that the PSOE is less (highly) centralized than the $\mathrm{PP}$ is also intriguing. If the main reason for continued internal centralization lays on the "power of the origins", we should not expect to find big differences within their internal power distribution. As we have said, there are no significant organizational differences between the ex novo creation of the AP-PP and the "recreation" of the PSOE after Franco's dictatorship.

Applying Van Biezen's argument on the salience of office overlapping to the regional context could be an explanation for both phenomena. Firstly, in spite of the transfer of powers and huge resources to Spanish regional governments, national party leaders could control the heads of those governments that belong to their parties by not allowing the latter to control their regional extra-parliamentary party and, as a result, their parliamentary support base in the regional legislative assemblies. Secondly, such a strategy would be accepted and implemented with more difficulty within a party, such as the PSOE, which defends regional self-rule as one of its ideological principles.

How can we know if national party leaders implement this strategy? There are several possible ways to find out, each of them with pros and cons. One possibility is to interview national and regional party leaders of both the Socialist and Popular parties who may have been involved in such processes over the past 30 years, and across the 17 "autonomous communities". Another possibility is to look for observable implications of the use of this "divide et impera" strategy, and test them in our case-study (King, Keohane and Verba 1994). In this article we have followed the second approach. The use of this strategy leads us to the following four expectations: 
Firstly, given Van Biezen's argument about the salience of office accumulation, and the fact that the main Spanish state-wide parties are said to be quite centralized, office overlapping will be significantly less common at the regional level than at the national level.

Still, we acknowledge the limitations of this approach. Most importantly that even if we do find such a difference, it does not in itself necessarily prove our reformulation of Van Biezen's argument as an explanation for the "resilient" centralization of Spanish state-wide parties. Perhaps other factors unrelated to our hypothesis lead to a lower degree of office accumulation at the regional level.

Nevertheless we think that if this "divide et impera" strategy is the explanation for this lower degree of office accumulation, we should also expect to find that office overlapping makes politicians that are both "top regional party leaders" and "regional premiers"3 more "autonomous" from their national headquarters than those who do not accumulate offices (see later for how we measure this). If office accumulation at the regional level were due to other factors unrelated to vertical power distribution issues, there should be no connection between office overlapping and the autonomy of both regional party leaders and premiers.

Thirdly, since it seems that the PP is even more centralized than the PSOE, we would expect that office overlapping will be more intense among the socialists than the conservatives.

And finally, we have also seen that scholars tend to suggest that, notwithstanding a high degree of centralization in both parties, a certain degree of decentralization has occurred anyway. This makes us expect that office overlapping will increase in both parties as the decentralization process in Spain gained momentum.

When analysing the accumulation of party and public office in new democracies Van Biezen (2000) reviewed an extensive variety of different public office holders: from presidents of the republic to members of national parliaments. Replicating her analysis and studying the different party offices held by all Socialist and conservative public office holders for each of the 17 "autonomous communities" for a period of around 30 
years would be an overwhelming task. Therefore, we have focused on the most important party and public offices: the top party leadership, the candidacy to the premiership of government, and the office of head of government.

In addition, given that both the PSOE and the PP are regarded as still quite centralized parties, it is probable that, if their regional leaders have gained -on average- some power, it is in the sense of obtaining "autonomy" for their own affairs rather than "influence" on national party politics. For this reason we will study whether regional politicians are more or less free to conduct their own affairs, and if office overlapping increases it. To infer their autonomy we focus on the following three indicators:

*Whether top regional party leaders "survive" or not a change of leadership at the national party organization.

One of the clearest examples of how Spanish national parties are still quite centralized is the fact that a change of leadership at the national level tends to be followed in the following months by changes of top party leaders in their regional branches. This change is facilitated because in both the PSOE and the PP most regional party congresses take place after the national congress so that the new national leaders can pressure for a removal of those unreliable or unsympathetic regional colleagues (Méndez 2000). But the more power top regional leaders have over their own regional organizations, the more difficult it will be for the national party to replace them as heads of the party branches. The period to assess this "survival" is approximately one year after the national party congress took place.

*Whether candidates for the presidency of regional governments, after losing their first elections, do not run again or have at least a second chance.

Irrespective of whether we assume that politicians are office seekers because it is a politician's highest aspiration or because it is the best way to influence public policy, it is not unreasonable to think that losing candidates would wish to run again ${ }^{4}$. However, a candidate that has led his/her party to electoral defeat will probably face a coalition of both activists disappointed by ideological concerns, or by losing the prospect of enjoying the spoils of politics, and fellow colleagues who see an opportunity to obtain 
the next party nomination. In the case of defeated regional candidates, they will also face the hostility of national colleagues that have missed the opportunity of controlling a regional government. This coalition of the discontented will find it difficult to organize, however, if the defection seems "temporal" and there is a credible chance that the same candidate will win next time. Improving results with respect to previous elections, although failing to win, can be an indicator of this. As a result, controlling for this fact, the more power regional candidates have over their own regional organizations, the more difficult it will be for the national party to bar them from running in the next elections.

*Whether regional premiers leave office either forced by the national leadership, or at least with their consent, or because of other reasons ${ }^{5}$.

This is without doubt one of the clearest indicators of the power that national party leaders have over their regional colleagues even if the latter chair a regional government. But, again, the more power regional premiers have over their own regional organizations, the more difficult it will be for the national party to remove them while in office or to bar them from running for another mandate.

The following study to test these expectations is based on a quantitative analysis of a database created by the author on the PSOE and PP official top party leaders in Spain's 17 "autonomous communities", their candidates to the presidency of regional governments, and regional premiers. The situation at the national level was also studied. The database starts in 1983, when the regional governments were generalized to the whole country, although we have also incorporated information for the five communities that held elections before that year. It ends in June $1^{\text {st }} 2009$. It is compiled based on information available on party and public administration web-sites, published memoirs of Spanish politicians, and a review of the Spanish press ${ }^{6}$.

\section{Results of the empirical analysis}

Descriptive data about regional party and public office holders 
According to our database, across the 17 Spanish "autonomous communities", between both parties there has been 166 top regional party leaders, 250 candidates (involving 135 different individuals) to the presidency of regional governments, and 62 regional premiers. In order to start giving meaning to these figures, we can compare them with the situation at the national level.

As we can see in table 1 for the three different "offices" the regional level present a consistently higher turnover. The average number of top regional party leader per region is higher than the number of top national party leaders, and consequently, the average duration at the highest party office has been shorter at this level. We can also see that there has been a higher number of different candidates per region than at the national level. Finally, there have been more regional premiers per autonomous community than prime ministers at the national level.

\section{[TABLE1]}

It is also interesting to note the variation we find in two of our three indicators of elite autonomy. Firstly, the proportion of regional candidates who lost the elections the first time they ran and had a second chance is inferior to the proportion of national candidates. Secondly, almost $42 \%$ of all regional presidents who have left office were forced to quit, or not to run again, by their national party organizations whereas all national prime ministers that have belonged to either party either lost the elections or voluntarily declined to run again. That means that regional premiers must be as attentive to how their regional citizens evaluate their government as to what their national leaders think of them. In sum, looking at these indicators, the image we obtain is that regional socialist and conservative party and public office holders are less powerful than their national counterparts as the existing qualitative literature suggests.

We can also check if this pattern at the regional level has experienced any variation as the process of state decentralization intensified. We have thus compared the data across two different periods. The first period is from the beginning of 1983 to the end of 1993; the second from the beginning of 1994 to mid-2009. As we can see in table 2 the turnover of to regional party leaders, candidates and regional premiers decreases with 
time, and the average duration of top regional party leaders has increased by almost one year.

\section{[TABLE 2]}

We can also see that the percentage of conservative top regional party leaders who "survive" a change of top national party leaders and, above all, the percentage of losing candidates with a second chance increase from the first to the second period. The percentage of regional premiers who were forced to leave while in office, or not to run again, also decreased, although only in the second case the difference is statistically significant. These facts are consistent with the view that regional politicians that belonged to state-wide parties gained some autonomy as the decentralization process intensified.

To finish presenting our data, we compare the two Spanish state-wide parties that we are analysing to see if there is any significant difference. As we can see in table 3 , it seems that the turnover of top regional party leader and regional premiers is slightly higher in the PP than in the PSOE. But the rest of indicators do not show clear differences. On the one hand, the percentage of top regional party leaders who "survive" a change of top national party leaders is slighter higher in the case of the $\mathrm{PP}^{7}$. On the other hand, the percentage of losing regional candidate with a second chance has been slightly higher in the Socialist party, and the percentage of its regional premiers removed by party central headquarters is smaller. In addition, most of these differences are not statistically significant. This is also consistent with the common view that both parties are similar from an organizational point of view.

\section{[TABLE 3]}

Is a "divide et impera" strategy employed at the regional level? Does "office accumulation" matter?

We can see now if the first expectation we had about office overlapping at the regional level being less intense than at the national level is confirmed by our data. 


\section{[TABLE 4]}

Table 4 shows that this expectation seems to be right. Candidates for the presidency of a regional government have tended to be the top party leaders less frequently than their national counterparts. As a result the percentage of top regional leaders who have also been heads of a government is smaller than the equivalent for national party leaders, and the percentage of regional premiers who were at the same time top party leader of their regions is also smaller than at the national level. This finding fits with our reformulation of Van Biezen's argument. National public office holders are also the official leader of "the party in central office" as part of their device to control the national parliamentary group, but tend to avoid this office overlapping at the regional level to keep their regional colleagues in line.

But it is true other factors that may be at play at the regional level, and that we simply ignore, could lead to the same result. Can be sure that office overlapping is related to regional political leaders' power? As we explained, we are going to assess if those regional politicians that are at the same time top party leaders, regional candidates and, if they win, also regional premiers are more "autonomous" than their counterparts that hold only one of these offices.

First of all, our data indicates that, in general, top regional party leaders increase substantially their chances of leaving their office when there is a previous change of leadership at the national party (see table 5$)^{8}$.

\section{[TABLE 5]}

Who are those top regional party leaders who, however, manage to "survive" that change of national leadership? Table 6 shows that, whereas all those top party leaders who are also regional premiers continue at the head of their party organizations, only $46.9 \%$ of those who are just top regional party leader do so. It is also interesting to note that what matters, is being regional premier, and not the fact that their party branch is in power. In fact, when top regional party leaders do not hold the premiership of a regional government, there is a lower ratio of survival if their party is in power at the regional level than in the opposition. These data seem to confirm the argument advanced by 
qualitative studies that the regional party leaders who are also regional premiers are stronger than those who are not (Méndez 2000).

\section{[TABLE 6]}

For assessing the effects of office overlapping on the chances a candidate for the premiership of a regional government has of running again after losing the first time, we have carried out a logistic regression. It employs as a dependent variable whether the regional candidate who lost an election on her/his first time did not have a second chance, or had another, or more, chances. As independent variables we have included if the candidate was the top regional party leader, and as control variables others factors that can also explain variation on their chances. First, the electoral evolution of the party with the defeated candidate in the regional elections (that is, if the party obtained better electoral results with the candidate even if s/he lost the election). Secondly, if her/his party was occupying the national government. This is a factor that is normally said to reinforce national party leadership and weaken regional politicians.

\section{[TABLE 7]}

From table 7 it is deduced that two factors count in determining a candidates" chance of competing again: either losing the elections, but obtaining better results than in previous elections, or being the top regional leader of the party. In other words, holding this party office protects a presidential candidate in the regional elections from not running again after bad electoral results.

In addition, it seems that the effect of being top party leader over repeating as candidate after failing the first time increases with time. Table 8 shows that, in the first period, what mattered was not if candidates controlled the regional party organization, but the results obtained on the first failed occasion. If they lost, but improved electoral results, they got at least a second chance as was expected. Interestingly in the second period things change dramatically. Now the electoral evolution stops being important. But if candidates are the top party leader in their region, in spite of their electoral results, the probability of repeating increases. This fact seems to suggest that regional party leaders, even if they are not in power, are increasingly stronger to the point that they are not 
being replaced by their regional colleagues or by their national ones even if they failed to win in their first election.

\section{[TABLE 8]}

In table 1 we have also seen that almost $42 \%$ of all presidents of regional governments who have left office were forced to quit, or not to run again, by their national party. So, what determines this? In order to answer this question we have carried out another logistic regression in which the dependent variable is if a head of a regional government quits, or declines to run again, forced by the national party leadership, or for any other reason. As independent variables we have used the number of year spent in office, the electoral strength of the regional premier (measured as the vote differential between her/his party and her/his main national competitor at the last regional elections before they left office), being at the same time the top regional party leader, and if the national party leadership is in the national government.

\section{[TABLE 9]}

As can be seen in table 9 it seems that what really counts is if the president of a regional government is at the same time the top regional party leader in his/her Autonomous Community, and not whether his/her national party is in government, his/her electoral strength, or the number of years spent in power. This suggests again that office accumulation does matter ${ }^{9}$.

Is there any difference across parties in their degree of office overlapping? We expected that, since the PP is allegedly even more centralized than the PSOE, and in line with Van Biezen's argument about the salience of office accumulation, then office overlapping at the regional level should be more intense among the socialists than among the conservative. Is that the case?

This expectation, however, is not confirmed by our data (see table 10). It is true that it has been more common for socialist top regional party leaders to be heads of regional government, a difference that is statistically significant. However, the rest of indicators show that office accumulation is higher in the case of the PP, although differences are 
nor statistically significant this time. We thus conclude that no real difference is found between these two parties.

[TABLE 10]

Finally, it has also been argued that as decentralization got deeper, regional governments were increasingly more powerful. We should expect then that office overlapping increases with at the regional level for this increase of power to have been possible.

[TABLE 11]

In table 11 we can see that there has been an increased tendency to choose top party leaders as candidates with time. The percentage of top regional party leaders who are heads of a regional government also has increased, although the difference is not statistically significant, and the percentage of regional premiers who were top regional party leaders has increased significantly. In brief, office overlapping increases as the decentralization process gained momentum.

\section{Discussion and first conclusions}

Over the past 30 years a large number of European and Latin American countries have experienced decentralization reform processes in their government structure. Initially it was believed that these processes were going to trigger a concomitant decentralization of state-wide parties. However, recent studies on some specific cases show that parties have changed less than expected. But, how national party leaders are able to counteract the decentralizing pressures that the first studies in this field underlined is usually unexplained.

In this article we have tested whether Van Biezen's mechanism for national political leaders in new democracies to have their parliamentary parties under control also applies to keep regional colleagues under control in one example of a new democracy. This scholar argued that the accumulation of party and public offices is part of a device 
for executives to control their parliamentary support base. By reformulating her proposal we have hypothesized that keeping party and public offices apart at the regional level maintains a chain of command whereby national party leaders are able to control their party's regional governments. When this "divide et impera" strategy is used, regional politicians will still depend on the goodwill of their national colleagues to repeat as candidates and, when in power, to govern, irrespective of the power and resources regional administrations have.

It is not an easy task to discover what strategies politicians actually perform to maintain their degree of power. As a result, we have looked for observable implications of our hypothesis, and tried to test them. We have seen that as we expect office overlapping is substantially less intense at the regional level than at the national level. In addition, we have also seen that office overlapping does seem to matter. Firstly, whereas all top regional party leaders that held executive office at the regional government have "survived" a change in the national party leadership, less than half of those that did not hold that office did so. Secondly, the probability of regional candidates, who failed to become regional premiers in their first attempt, having another opportunity increases if they are top regional party leaders. We have also seen that in the last few years this has been the only variable that has mattered. Finally, holding the top regional party office was important for ensuring that regional premiers were not expelled from government by their national colleagues. In brief, those politicians that hold both party and public offices are more autonomous than their regional colleagues that are either only top regional party leaders or regional premiers. These findings seem to fit with what we would expect to find if national party leaders tried to use a "divide et impera" strategy.

The findings also qualify a standard explanatory factor underlined by existing literature. What gives power to regional politicians of the main Spanish state-wide parties is not merely holding government power, as previous qualitative studies have stressed. It is true that socialist and conservative top party leaders who were regional premiers were more able to survive a change of top national party leaders. But we cannot forget that almost $42 \%$ of the heads of regional governments were forced to quit, or not to run again, by their national party leaders. However, holding the leadership of the regional party organization was a kind of guarantee against being barred to continue as head of a 
regional government. It also protected a presidential candidate in the regional elections after bad electoral results.

However, our expectation that office overlapping will be more intense within the PSOE regional level than in the PP is not confirmed by our data. Perhaps the Spanish conservatives exercise control thorough other means we have not captured. This is a possibility. Another possibility is that the claims of current qualitative studies that the PSOE is less centralized than the PP are somehow overstated. Further research on this is required.

Finally our fourth expectation that if regional politicians are increasingly more powerful, as the qualitative literature tends to claim, office accumulation would increase across time is confirmed by our data. Still this finding introduces a certain puzzle. If this "divide et impera" strategy allows national party leaders to control regional politicians, why is it less employed across time? That regional governments are more powerful as the state decentralization intensified cannot be the answer, since this strategy is precisely designed to keep in line those regional politicians who chair regional governments.

One possibility could be that national party leaders eventually discover that that their "divide et impera" strategy weakens their regional party branches, and become more cautious in using it. If, for example, those regional candidates that do not hold at the same time the top party office had a weaker support by their regional organization at the sub-national elections, or if regional premiers that do not hold that party office were undermined by their own regional parliamentary parties, this strategy would result in making regional party branches less competitive vis-à-vis rival parties. Is there then a dilemma for national politicians between weakening regional colleagues to keep them under control, and reinforcing them to make them electorally competitive? This also needs further research. 


\section{FIGURES AND TABLES}

Figure 1: Spanish regional governments presided over by the PSOE and the PP (at the beginning of each natural year)

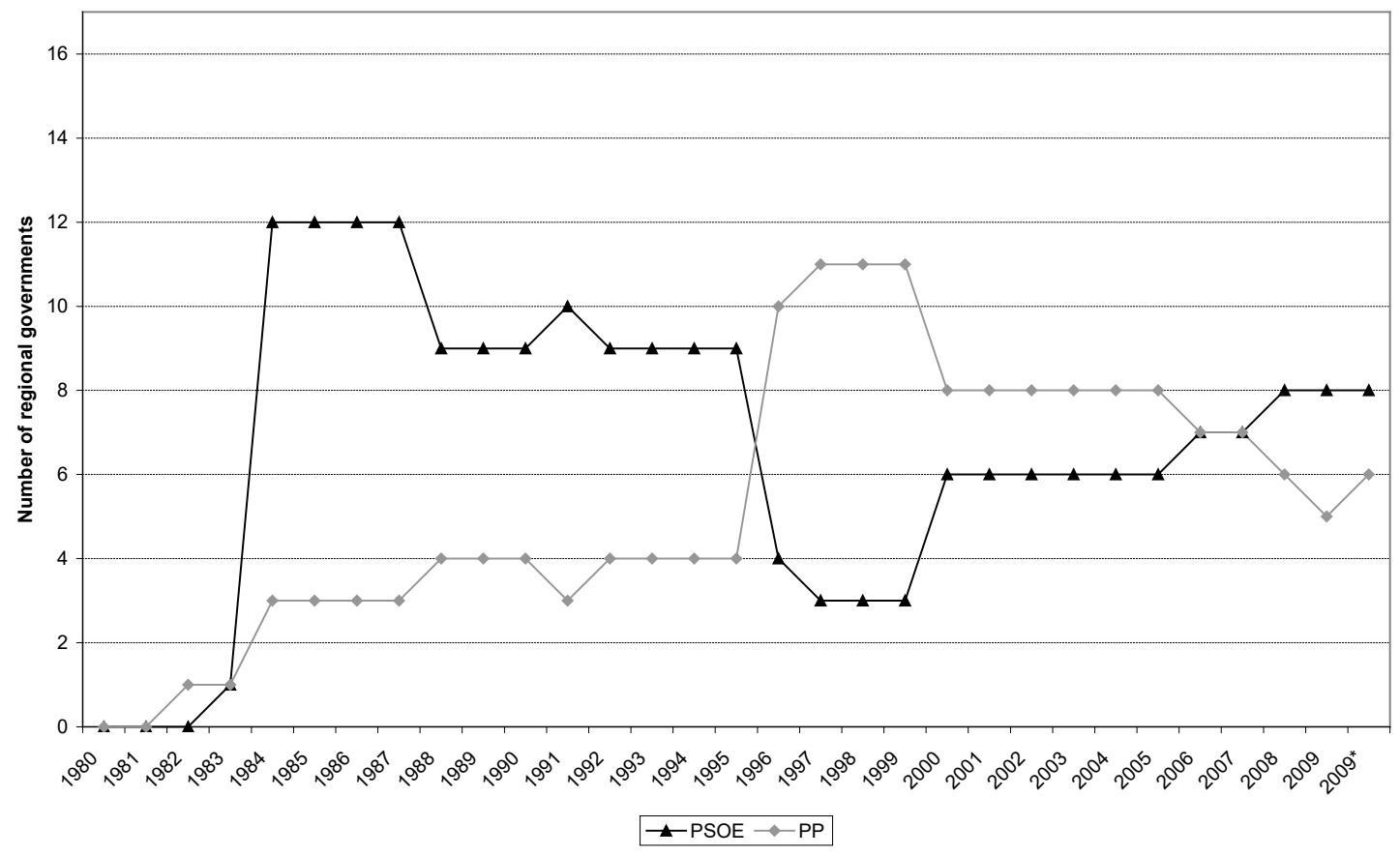

Source: own elaboration from internal data from the Ministry of Public Administration. *At June $1^{\text {st }} 2009$

Table 1: Comparison of regional and national party and public office holders, 1983-2009 (only PSOE and PP politicians)

\begin{tabular}{lcc}
\hline & Regional level & National level \\
\hline Total number of top party leaders & 166 & 8 \\
Average number of top party leaders per region & 9.8 & n.a. \\
Average duration of top party leaders (in years) & 2.8 & 3.4 \\
Percentage of top regional party leaders who "survive" a & $57.4 \%$ & n.a \\
change of top national party leaders & & \\
\hline Total number of (different) candidates & 135 & 6.9 \\
Average number of (different) candidates per election (and & 1.1 & \\
autonomous community at the regional level) & & $75.0 \%$ \\
Percentage of losing candidates with a second chance & $44.2 \%$ & 3 \\
\hline Total number of "heads of government" & 62 & \\
\hline
\end{tabular}




\begin{tabular}{lcc}
\hline Average number of regional premiers per region & 3.6 & n.a. \\
Average duration of "heads of government" (in years) & 6.9 & 8.3 \\
$\begin{array}{l}\text { Percentage of heads of government forced to leave office, } \\
\text { or not to run again, by their national party }\end{array}$ & $41.7 \%$ & $0.0 \%$ \\
\hline
\end{tabular}

Source: Author's elaboration. N.a. Not aplicable.

Table 2: Comparative data 1983-2009 of party and public office holders leaders in the 17 "autonomous communities" (both parties)

\begin{tabular}{lcc}
\hline & $1983-93$ & $1994-2009$ \\
\hline Total number of top regional party leaders ${ }^{1}$ & 100 & 100 \\
Average number of top party leaders per region & 5.9 & 5.9 \\
Average duration of top regional party leaders (in years) & 1.9 & 2.7 \\
$\begin{array}{l}\text { Percentage of top regional party leaders who "survive" a } \\
\text { change of top national party leaders (only PP) }\end{array}$ & $54.9 \%$ & $70.6 \%$ \\
\hline Total number of (different) candidates & & \\
Average number of (different) candidates $\quad$ per & $1,5^{*}$ & $0,9 *$ \\
region/election & & $61.2 \% *$ \\
Percentage of losing candidates with a second chance & $29.3 \% *$ & 27 \\
\hline Total number of regional premiers & 35 & 1,6 \\
Average number of regional premiers per region & 2,1 & 10 \\
Average duration of regional premiers (in years) & 5,2 & $36.8 \%$ \\
Percentage of regional premiers forced to leave office, or & $42.9 \%$ & \\
not to run again, by their national party & & \\
\hline
\end{tabular}

Source: Author's elaboration. *The asterisks indicate that such statistics are significant at a confidence level of $95 \%$.

1: Given that some party leaders continue in the second period, they are counted twice.

2: Since in the first time period the PSOE did not change its national party leader, we only study the PP.

Table 3: Overall comparison of PSOE and AP/PP party and public office holders (1983-2009)

\begin{tabular}{lcc}
\hline & PSOE & PP \\
\hline Total number of top regional party leaders & 71 & 95 \\
Average number of top party leaders per region & $4.2^{*}$ & $5.6^{*}$ \\
Average duration of top regional party leaders (in years) & $6.4^{*}$ & $4.9^{*}$ \\
\hline
\end{tabular}




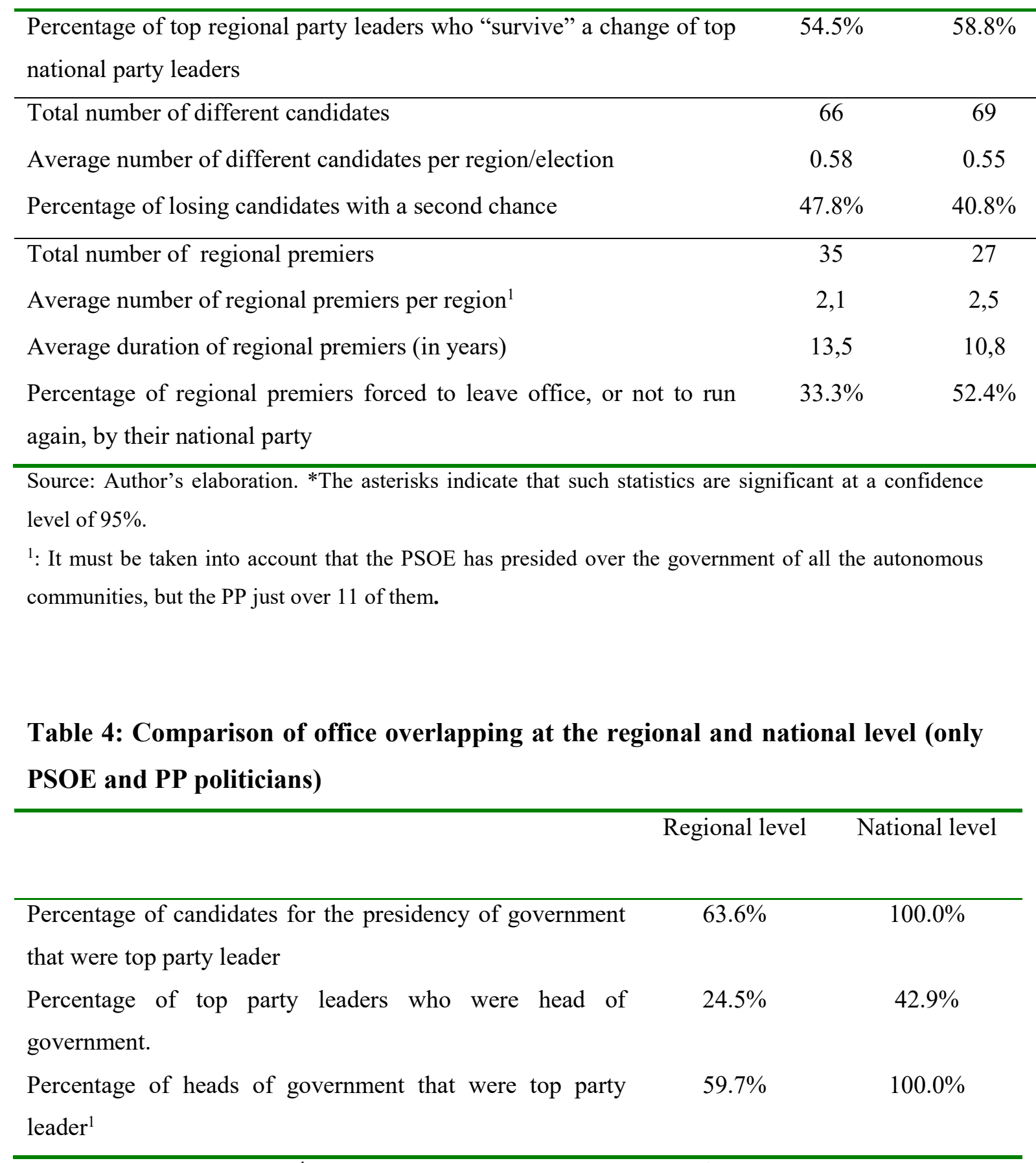

Source: Author's elaboration. ${ }^{1}$ : Situation when leaving office or on June $1^{\text {st }} 2009$.

Table 5: Probabilities of leaving the office of top regional party leader conditional to a change of the party national leadership

\begin{tabular}{lccc}
\hline ¿Is there a change of leadership at the national & Mean & $\mathrm{N}^{1}$ & Std. dev. \\
level? & & & \\
\hline No & .13 & 816 & .332 \\
Yes & .32 & 102 & .470 \\
Total & .15 & 918 & .355 \\
\hline
\end{tabular}




\begin{tabular}{ll}
\hline Eta $^{2}$ & 0.175 \\
Sign. & 0.000 \\
\hline
\end{tabular}

${ }^{1}$ : The cases are "region-year"

Table 6: Percentages of top regional party leaders who "survive" a previous change of party leadership at the national level depending on office accumulation and incumbency

\begin{tabular}{lccc}
\hline & $\begin{array}{c}\text { Continues as top } \\
\text { regional party leader }\end{array}$ & $\begin{array}{c}\text { Stops being top regional } \\
\text { party leader }\end{array}$ & Total \\
\hline $\begin{array}{l}\text { The top regional party leader is } \\
\text { also regional premier }\end{array}$ & $100.0 \%^{*}$ & $0.0 \%^{*}$ & $100.0 \%$ \\
$\begin{array}{l}\text { The top regional party leader is not } \\
\text { regional premier }\end{array}$ & $46.9 \%^{*}$ & $53.1 \%^{*}$ & $100.0 \%$ \\
\hline $\begin{array}{l}\text { The top regional party leader is not } \\
\text { regional premier, but his/her party } \\
\text { chairs the regional government }\end{array}$ & $20.00^{*}$ & $80.0 \% *$ & $100.0 \%$ \\
$\begin{array}{l}\text { The top regional party leader is not } \\
\text { regional premier, and his/her party } \\
\text { does not chair the regional } \\
\text { government }\end{array}$ & $53.0 \% *$ & $47.0^{*}$ & $100.0 \%$ \\
\hline Total & & & \\
\hline
\end{tabular}

Source: Author's elaboration. ${ }^{*}$ The asterisks indicate that such statistics are significant at a confidence level of $95 \%$.

${ }^{1:}$ It includes the situation of the party being in power and in the opposition.

Table 7: Explanatory factors for the opportunities offered to candidates losing regional elections, 1983-2009 (only PSOE and PP) 
Constant

Positive electoral evolution of the party with respect to previous regional $.104^{* *}$ elections

The regional candidate was the top regional party leader

The national party of the regional candidate was in national government $\quad .066$

$(.537)$

\section{Chi2}

$15.370^{* * *}$

$-2 \log$ of likelihood

94.034

$\%$ predicted

69.6

$\mathrm{R}^{2}$ of Nagelkerke

.236

$\mathrm{N}$

79

In brackets, the typical error. ${ }^{* * *}$ significant at $1 \%{ }^{* *}$ significant at $5 \%$.

Table 8: Explanatory factors for the opportunities offered to candidates losing regional elections (only PSOE and PP)

\begin{tabular}{lll}
\hline & Period 1983-1993 & Period 1994-2009 \\
\hline Constant & -1.353 & .237 \\
& $(.775)$ & $(.560)$ \\
Positive electoral evolution of the party to & $.171^{* *}$ & .012 \\
previous regional elections & $(.077)$ & $(.068)$ \\
The regional candidate was the top regional & .982 & $1.846^{* *}$ \\
party leader & $(.871)$ & $(.764)$ \\
The national party was in the national & 1.470 & -1.403 \\
government & $(.989)$ & $(.847)$ \\
\hline Chi2 & $10.227^{* *}$ & $9.581^{* *}$ \\
-2 log of likelihood & 32.113 & 52.977 \\
$\%$ predicted & 81,3 & 66 \\
$\mathrm{R}^{2}$ of Nagelkerke & .373 & .251 \\
$\mathrm{~N}$ & 32 & 47 \\
\hline
\end{tabular}

In brackets, the typical error. $* * *$ significant at $1 \% * *$ significant at $5 \%$. 
Table 9: Explanatory factors for the end of a regional premier, 1983-2009 (only PSOE and PP)

Fall of a regional premier

(forced vs other reasons)

\section{Constant}

$-1.909$

Number of years as regional premier

Electoral strength of the regional premier

The regional premier was the top regional party leader

The national party of the regional premier was in the .884 national government

\begin{tabular}{ll}
\hline Chi2 & $14.497^{* * *}$ \\
-2 log of likelihood & 27.843 \\
\% predicted & 81.3 \\
$\mathrm{R}^{2}$ of Nagelkerke & .497 \\
$\mathrm{~N}$ & 32 \\
\hline
\end{tabular}

In brackets, the typical error. $* * *$ significant at $1 \% * *$ significant at $5 \%$.

Table 10: Comparison of office overlapping in the PSOE and PP at the regional level (1983-2009).

\begin{tabular}{lcc}
\hline & PSOE & PP \\
\hline $\begin{array}{l}\text { Percentage of candidates for the presidency of regional governments } \\
\text { that were top regional party leaders }\end{array}$ & $58,7 \%$ & $68,5 \%$ \\
$\begin{array}{l}\text { Percentage of top regional party leaders who were also regional } \\
\text { premiers }\end{array}$ & $33.8 \% *$ & $17.6 \%^{*}$ \\
$\begin{array}{l}\text { Percentage of regional premiers who were also top regional party } \\
\text { leader }\end{array}$ & $63.8 \%$ & $75.9 \%$ \\
\hline
\end{tabular}

Source: Author's elaboration. ${ }^{*}$ The asterisks indicate that such statistics are significant at a confidence level of $95 \%$.

1: Situation when leaving office or on June $1^{\text {st }} 2009$. 
Table 11: Comparison of office overlapping across time at the regional level (only PSOE and PP).

\begin{tabular}{lcc}
\hline & $1983-93$ & $1994-2009$ \\
\hline $\begin{array}{l}\text { Percentage of candidates for the presidency of regional } \\
\text { governments that were top regional party leaders }\end{array}$ & $56.0 \%{ }^{*}$ & $70.4^{*}$ \\
$\begin{array}{l}\text { Percentage of top regional party leaders who were heads of a } \\
\text { regional government }\end{array}$ & $24.4 \%$ & $26.2 \%$ \\
$\begin{array}{l}\text { Percentage of regional premiers that were top regional party } \\
\text { leader }\end{array}$ & $58.9 \% *$ & $78.3^{*}$ \\
\hline
\end{tabular}

Source: Author's elaboration. ${ }^{*}$ The asterisks indicate that such statistics are significant at a confidence level of $95 \%$.

1: Situation when leaving office or on June $1^{\text {st }} 2009$. 


\section{References}

Astudillo, Javier (2010), "El Partido Popular: un partido regionalizado, no descentralizado", in F. Pallarés (ed.), Competencia política multinivel: ciudadanos, partidos y elecciones en el Estado de las Autonomías, Valencia. Tirant Lo Blanc (forthcoming).

Bowler, Shaun, Farrell, David, and Richard, Katz (1999), Party Discipline and Parliamentary Government, Ohio: Ohio University Press.

Bratberg, Oividind (2010), "Institutional Resilience Meets Critical Junctures: (re)allocation of power in three British parties post-devolution”, Publius, 40: 59-81.

Deschouwer, Kris (2006), "Political Parties as Multi-level Organizations", in K. Richard and W. Crotty, Handbook of Party Politics. London: Sage Publications.

Detterbeck, Klaus, and Hepburn, Eve (2009), "Party Politics in Multi-level Systems: Party Responsens to New Challenges in European Democracies", in W. Swenden and J. Erk (eds), Exploring New Avenues of Comparative Federalism Research. London: Routledge.

Duverger, Maurice (1988), Los Partidos Políticos, México: Fondo de Cultura Económica.

Fabre, Elodie (2008), "Party Organization in a Multi-level System: Party organizational Change in Spain and the UK", Regional \& Federal Studies, Vol. 18, No. 4, pp 309329.

García-Guereta, Elena (2001), Factores Externos e Internos en la Transformación de los Partidos Políticos: El caso de AP-PP. Madrid: Instituto Juan March de Estudios e Investigaciones.

Gómez Sala, Salvador, and Sánchez, José (2009), “Análisis Regional del Empleo Público en España”, XVI Encuentro de Economía Pública, "Crisis Financiera y Sector Público”, Granada, 5 y 6 de febrero 2009.

Harmel, Robert (2005), “Party Organizational Change”, in K. R. Luther and F. MüllerRommel (eds) Political Parties in the New Europe, Oxford: Oxford University Press.

Hopkin, Jonathan (2003), "Political Decentralization, Electoral Change and Party Organizational Adaptation", European Urban and Regional Studies, Vol. 10. pp. 227-237. 
Hopkin, Jonathan (2009), "Party Matters: Devolution and Party Politics in Britain and Spain”, Party Politics, Vol. 15, pp. 179-198.

Janda, Kenneth (1980), Political Parties: A cross-national survey. New York: The Free Press.

Kam, Christopher J. (2009), Party Discipline and Parliamentarian Politics, Cambridge: Cambridge University Press.

King, Gary, Keohane, Robert, and Verba, Sidney (1994), Designing Social Inquiry, Princeton: Princeton University Press.

Laffin, Martin, Shaw, Eric, and Gerald Taylor (2007), “The new Sub-National Politics of the British Labour Party", Party Politics, Vol. 13. No. 1, pp. 88-108.

Maravall, José María (1991), "From Opposition to Government: the politics and policies of the PSOE", in J.M. Maravall (et al.) Socialist Parties in Europe, Barcelona: ICPS.

Méndez, Mónica and Orte, Andreu (2010), "La Organización de Partidos en Sistemas Multinivel: el caso del PSOE”, in F. Pallarés (ed.), Competencia política multinivel: ciudadanos, partidos y elecciones en el Estado de las Autonomías, Valencia. Tirant Lo Blanc (forthcoming).

Méndez, Mónica (2000), La Estrategia Organizativa del Partido Socialista Obrero Español (1975-1996), Madrid: Centro de Investigaciones Sociológicas.

Mitxelena, Carmen (2006), "Descentralización fiscal y cohesión territorial en España”, Principios, vol. 4.

Montero, Alfred (2005), "The Politics of Decentralization in a Centralized Party System: The case of Democratic Spain”, Comparative Politics, Vol. 38, pp. 63-82.

Moreno, Luis (1997), La Federalización de España, Madrid: Siglo XXI.

OCDE, (2005), “Spain 2005”. OECD Economic Surveys. Vol. 2005/6

Poguntke, Thomas, Webb, Paul (2005), The Presidentialization of Politics, Oxford: Oxford University Press.

Rodden, Jonathan (2004), "Comparative Federalism and Decentralization: On meaning and measurement". Comparative Politics, Vol. 36, pp. 481-500.

Roller, Elisa and Van Houten, Pieter (2003), “A National Party in a Regional Party System: The PSC-PSOE in Catalonia”, Regional \& Federal Studies, Vol. 13, No. 3, pp. 1-22.

Thorlakson, Lori (2009), "Patterns of Party Integration, Influence and Autonomy in Seven Federations", Party Politics, Vol. 15, No. 2, pp. 157-177. 
Van Biezen, Ingrid (2003), Political Parties in New Democracies. New York: Palgrave Macmillan.

Van Biezen, Ingrid, and Hopkin, Jonathan (2005), “The Presidentialization of Spanish

Democracy", in T. Poguntke and P. Webb (eds), The Presidentialization of Politics, Oxford: Oxford University Press.

Van Biezen, Ingrid, and Hopkin, Jonathan (2006), "Party organisation in multi-level contexts" in D. Hough and C. Jeffery (eds), Devolution and Electoral Politics, Manchester University Press: Manchester.

Woldendorp, Jaap, Keman, Hans, and, Ian Budge (1998), "Party Government in 20

Democracies: An up-date (1990-1995)", European Journal of Political Research 33

(1): $125-64$.

${ }^{1}$ Other studies have also noted the role of some intervening variables such as type of federalist arrangements, electoral laws, election cycle overlapping, and the existence of diverse "ethnic" identities within a state in the state-wide party transformation (Chandler 1987, Roller and Van Houten 2003, Deschouwer 2006, Fabre 2008, Thorlakson 2009).

${ }^{2}$ In both parties regional branch party leaders are formally elected by regional party congresses. However, for candidate selection for regional elections, the regional party leadership draws up lists which are then submitted for approval to the national leadership.

${ }^{3}$ In Spain the heads of regional governments are called "presidents". This term is confusing as the official heads of party organizations in the Conservative party are also called "presidents' ("secretary-general" in the case of the Socialist Party). In order to avoid this confusion and use terms than can be employed for both parties, we call the first political actors "regional premiers", and the second ones "top regional party leaders". When we refer to both kinds of actors without specifying if they accumulate or not both party and public office, we call them "regional leaders, or regional politicians".

${ }^{4}$ Obviously personal predispositions about one's capabilities matter, but this effect should be random.

5 The other reasons that were studied were: upward promotion to national leadership, voluntary resignation, forced resignation by other parties in the government coalition, vote of no confidence from the opposition, and electoral defeat. This is an adaptation of Wondeldorp, Keman and Budge (1998)`s reasons for termination of national governments applied to the regional context

${ }^{6}$ For the 1980s and 1990s the Spanish newspapers El Pais and La Vanguardia have been used. After 2000 also El Mundo and $A B C$.

${ }^{7}$ The results of this comparison must be regarded with caution since the PP tended to have most changes of national party leader in the first time period ( 3 versus 1 ) whereas in the case of the Socialist Party the two of them happened in the second period.

${ }^{8}$ As we explained, national party congresses precede regional ones. This fact rules out the possibility that national leadership changes because newly selected regional party leaders get rid of the old national leaders.

${ }^{9}$ Given the small number of cases we could not study the time effect on being removed as regional premier. 